\title{
Do Small and Mid-scale Beginning Farmers and Experienced Farmers Feel the Same About Farm Financial and Profitability Position?
}

\author{
Jean D. Gumirakiza ${ }^{1} \&$ Spencer Langford $^{1}$ \\ ${ }^{1}$ Department of Agriculture \& Food Science, Western Kentucky University, Bowling Green, KY, USA \\ Correspondence: Jean D. Gumirakiza, Department of Agriculture \& Food Science, Western Kentucky University, \\ EST 237, 1906 College Heights BLVD \# 410066. Bowling Green, KY 42101, USA. Tel: 1-270-745-5959. \\ E-mail: dominique.gumirakiza@wku.edu
}

$\begin{array}{lc}\text { Received: August 6, } 2020 & \text { Accepted: September 11,2020 Online Published: October 15, } 2020 \\ \text { doi:10.5539/jas.v12n11p8 } & \text { URL: https://doi.org/10.5539/jas.v12n11p8 }\end{array}$

The research is financed by USDA-NIFA.

\begin{abstract}
This study examined various levels of feelings that small and mid-scale farmers in Kentucky have towards financial and profitability situations of their farm operations. The study uses mailed and online survey data collected from 129 small and mid-scale farmers in 2017. We used an ordered Probit model to analyze data. Findings indicate that the probabilities for small and mid-scale farmers to feel positively, fairly, and negatively are 36 percent, 55 percent, and 9 percent, respectively. We found that small and mid-scale beginning farmers are significantly less likely to feel positively than experienced farmers. Findings showed that those who are knowledgeable about agricultural marketing and agricultural economics are more likely to feel positive. These findings are useful for policymakers, outreach specialists, and other agencies seeking to improve the financial and profitability position of small and mid-size farms.
\end{abstract}

Keywords: Small and mid-scale farmers, feelings, financial and profitability position.

\section{Introduction}

Producers' feelings about financial and profitability position in any industry play an important role in influencing its performance. Agricultural industry is not an exception to this fact. Dedehouanou and Maertens (2011) found that farmers' relative feelings about their finances have a significant impact on their overall happiness. Austin and Mohammed (2013) and Maharajh et al. (2018) reported that labor and production costs reduce farm profits and therefore shape feelings among farmers. Ahearn (2011) indicated that there are numerous challenges small and/or beginning farmers face; leading to negative feelings. Some of the challenges include the barrier to obtaining capital and the learning process of running a successful farm. These are often stressful experiences for a producer. Katchova (2010) and Calo (2018) found that young and beginning farmers are much more likely to experience financial hardship.

Although there have been some studies related to this topic, knowledge about feelings among small and mid-scale farmers in Kentucky is still limited. This study primarily focused on explaining how small and mid-scale farmers in Kentucky feel about their farm financial and profitability positions. The study pays attention to examining whether beginning farmers/ranchers and their more experienced counterparts have different feelings. The U.S. Department of Agriculture (2019) defines beginning farmers/ranchers as those who have been the primary farm/ranch operator less than 10 years. Several of these farmers operate small and mid-sized farms; which is the focus of this study. These producers are in a unique situation compared to larger sized operations.

Specific objectives for this study were to: (i) Estimate relative probabilities for small and mid-scale farmers to feel positively, fairly, or negatively respectively. (ii) Identify and explain significant factors that influence feelings that small and mid-scale farmers in Kentucky have about financial position and profitability position of their farm operations. (iii) Determine the probability difference between beginning farmers and experienced farmers regarding feelings about financial position and profitability of their farm operations. This study is relevant and significant. It allows a clear understanding of how farmers feel about the financial position and 
profitability of their farm operations. It also assists those in the agriservice sector of the agribusiness system to better service the needs of small and mid-scale farmers. Nambiro et al. (2006) indicated that those who are of lower income were less likely to use agriservices. Furthermore, this study is important for policy makers in their efforts to provide support that could improve financial and profitability positions among small and mid-scale farmers.

\section{Literature Review}

As previously stated, the literature related to this topic is limited. Some, but not all, of the previous studies (Maharajh et al., 2018; Möllers et al., 2009; O’Leary et al., 2017) about closely-related topics used survey data and applied ordered Probit/Logit model. Other studies like Samdup, Udo, and Van der Zijpp (2014) used a gross national happiness guideline while O'Leary et al. (2017) and Maharajh et al. (2018) utilized various types of regression analysis. Age, education, and experience are consistent variables across a majority of studies. Previous results seem to differ based on where the studies took place. Location matters because issues and attitudes among farmers vary by region and the general state of agriculture in their locality. Estimating individuals' feelings is not a new concept. Latvala and Pyykkonen (2005); Samdup, Udo, and Zijpp (2014) focused on this concept. Surveys that attempt to estimate one's happiness are somewhat similar to "willingness-to-pay" surveys in that they are subjective.

Poczta-Wajda (2015) indicated that financial positions play a significant role in farmers' levels of happiness. The study found that most farmers in wealthy countries tend to compare their financial standing to that of the much wealthier non-agricultural laborers around them. This led to many farmers in wealthy countries to be less likely to feel financially well off. Frey (2018) indicated that when measuring individuals' happiness, there are other factors to consider; such as health or job security. Mishra et al. (2002) used many variables to show the complexity of understanding farmers' feelings in the United States. They discussed aspects such as off-farm income and investments. Ultimately, they found that farm households as a whole were financially better off than the U.S. average. Samdup, Udo, and Van der Zijpp (2014) found that small and mid-scale farmers were mainly concerned with socioeconomic and environmental issues.

Farm profitability is a key aspect to determine happiness among farmers. O'Leary et al. (2017) indicated that most farmers are mainly concerned with generating a profit. This same study also found that an increase in net worth is crucial to farmers feeling successful. The concept of profitability being an important aspect of farmer attitudes is largely true. Latvala and Pyykkonen's (2005) indicated that profitability was the main factor behind the decision to upgrade technology on dairy farms. They further found that personal preferences was a significant factor and that farmers with higher incomes tended to be concerned with profit more.

Katchova (2010) provides more evidence of the difficulties for beginning and small farmers. In that study, beginning young and small farmers were more likely to experience financial stress compared to more experienced ones. Calo (2018) conducted a qualitative study among beginning Latino farmers in California. That study found a level of frustration with inefficiencies in government outreach programs and difficulties to access capital. Another qualitative study by Jablonski et al. (2017) found an increase in profitability after producers were engaging in a program geared towards young farmers. Poczta-Wajda (2015) found that farmers often feel relatively deprived, as they tend to compare themselves to those in better financial standing.

\section{Methodology}

\subsection{Data Collection}

This study used data collected in 2017 from small and mid-scale farmers via both mail and online anonymous surveys. We identified research participants from a public directory of farmers available at the Kentucky Department of Agriculture. The directory displays contact information like phone numbers, emails, and/or mail addresses. We randomly selected 850 farms and mailed the surveys to farm owners. The survey included an electronic link for those who preferred taking the survey online. In order to encourage participation, we offered a chance to win one of five $\$ 50$ Visa gift cards.

To ensure that the use of data from small and mid-scale farmers only, we asked study participants to indicate a category that best corresponds to annual gross farm sales categories [(1) less than \$250,000, (2) $\$ 250,001-\$ 500,000$, and (3) more than \$500,000] for the previous year; 2016. In total, we received 138 completed surveys. We excluded nine whose annual farm sales were more than $\$ 500,000$. This is consistent with USDA's definition of small and mid-scale farms. Therefore, this study used data from 129 survey participants.

The survey included several questions. Many questions were about farmers' characteristics while few others asked information about farm attributes. For the dependent variable in this analysis, we used answers to the 1-3 
scale question about levels of feelings that small and mid-scale farmers have towards financial and profitability positions of their farm operations. We told respondents that the farm financial position looks at the balance sheet and indicates the ability for the farm to have enough liquidity to pay its debts as they come due. We also told them that profitability position focuses on the farm income statement to measure the degree the farm uses its assets to generate its income. We then asked the following question: "How do you feel about the financial position and the profitability of your farm operation?" Three choice options/alternatives were part of the choice set: (1) I feel negatively, (2) I feel fairly, and (3) I feel positively. We used responses from this question as a dependent variable.

\subsection{Model Specification}

Theoretically, this analysis falls within the choice model framework. From a modeling perspective, a feeling level 3 is higher than 2; which is higher than 1 . We used $U$ to denote a function that represents the feelings. Higher values of $U$ indicate greater feelings and lower values posit otherwise. Consequently, we used an ordered Probit model. The reason is that Train (2009) and Kennedy (2008) indicated that an analysis whose dependent variable is of this nature, an ordered Probit or Logit model is the most appropriate approach. We assume that the random error term is normally distributed $N(0, \Omega)$. Because of this assumption, Train (2009) indicated that the Probit model must be applied. Theoretically, for individual respondent farmer $i$ choosing a specific $j$ option/alternative, his/her $U$ can be decomposed into two components; observed and unobserved as follows:

$$
U_{i j}=\beta^{\prime} X_{i j}+\varepsilon_{i j} \text { for } i=1, \ldots I \text { and } j=1, \ldots J
$$

The $\beta X_{i j}$ in Equation (1) is the observed component of $U$. The parameter $\beta$ represents a vector of coefficient estimates and differs across choice options/alternatives. The $\varepsilon_{i j}$ is an error term represented by random factors that we, as researchers, cannot observe. We observe chooser's characteristics and the attributes of the choices made. If the $U$ is above some cutoff; labeled as $u_{1}$, the respondent chooses the highest choice option. If it is below $u_{1}$ but above another cutoff, $u_{2}$, then the respondent chooses the next lower option and so on. Within the context of this study, Equation (2) represents each chooser's choice decision $(y)$ :

$$
\mathrm{y}=\left\{\begin{array}{c}
1 \text { if } 0<V_{i j}^{*} \leq \mu_{1} \\
2 \text { if } \mu_{1}<V_{i j}^{*} \leq \mu_{2} \\
\cdots, \\
\text { Jif } \mu_{J-1}<V_{i j}^{*} \leq \mu_{J}
\end{array}\right.
$$

The $\mu$ 's in (2) above are unknown threshold parameters that will be estimated together with the $\beta$ 's. The $V_{i j}{ }^{*}$ represents the observed component of the function $U$. Because respondents expressed their ordered levels of feelings, we interpret the coefficients estimates as ordered log-odds. They measure the impact of corresponding $X_{i j}$ variable on the chances of the feelings to be positive over chances of fair or negative. For binary explanatory variables, the coefficients indicate the probability difference between $X_{i j}$ values of zero and one. Equation (3) below represents the likelihood that $y$ will take on a particular value $j$ (assigned to the choice alternatives in the choice set).

$$
\text { Prob }(y=j \mid X)=\exp \left(\beta^{\prime} X\right) /\left[1+\exp \left(\beta^{\prime} X\right)\right]
$$

In this analysis, we hypothesized in null terms that chooser's characteristics have no impact on how respondents feel about the financial position and profitability of their farm operations; i.e., $\mathrm{H}_{0}: \beta_{k}=0$, where, $k$ denotes a specific explanatory variable. We alternatively hypothesized that chooser's characteristics have significantly different from zero (either positive or negative) impact on how respondents feel about the financial position and profitability of their farm operations; i.e., $\mathrm{H}_{1}: \beta_{k} \neq 0$.

\section{Presentation and Discussion of Results}

\subsection{Descriptive Statistics}

Table 1 displays descriptive statistics about the small and mid-scale farmers who participated in this study. We conveniently presented the statistics for each of the three feeling levels. 
Table 1. Descriptive statistics

\begin{tabular}{|c|c|c|c|c|}
\hline \multirow{2}{*}{ Respondents Characteristics and their description } & \multicolumn{3}{|c|}{ Feelings about Farm Financial } & \multirow{2}{*}{ Total } \\
\hline & Feel Negatively & Feel Fairly & Feel Positively & \\
\hline Beginning Farmers ( 1 if respondent has less than 10 years of farming, 0 otherwise). & .27 & .48 & .25 & .43 \\
\hline Beginning_Female ( 1 for female beginning farmer, 0 otherwise). & .37 & .48 & .15 & .21 \\
\hline FiftyandOlder ( 1 for 50 and above years old, 0 otherwise). & .18 & .46 & .36 & .54 \\
\hline Fulltime_Beginners ( 1 for a fulltime beginning farmer, 0 otherwise). & .20 & .53 & .27 & .12 \\
\hline BPFM_User ( 1 for users of best practices of farm management, 0 otherwise). & .14 & .43 & .43 & .81 \\
\hline Female ( 1 for female, 0 otherwise). & .25 & 50 & .25 & .38 \\
\hline FarmFullTime ( 1 for a fulltime farmer, 0 otherwise). & .12 & .40 & .48 & .33 \\
\hline Married ( 1 for married respondent, 0 otherwise). & .18 & .49 & .33 & .76 \\
\hline Married_Beginners (1 for a married beginning farmer, 0 otherwise). & .34 & .51 & .15 & .30 \\
\hline Educated_Female ( 1 for a female with at least 4 -year college degree, 0 otherwise). & .26 & .48 & .26 & .21 \\
\hline $\begin{array}{l}\text { Educated_Beginners ( } 1 \text { for a beginning farmer with at least } 4 \text {-year college degree, } \\
0 \text { otherwise). }\end{array}$ & .37 & .36 & .27 & .23 \\
\hline FourYearCollegeGrad ( 1 for at least 4-year college, 0 otherwise). & .19 & .40 & .41 & .49 \\
\hline Married_Female ( 1 if respondent is married female, 0 otherwise). & .29 & .50 & .21 & .55 \\
\hline $\begin{array}{l}\text { ExtensionGovFundUser ( } 1 \text { if respondent uses extension services and/or any } \\
\text { other government-funded program, } 0 \text { otherwise). }\end{array}$ & .11 & .41 & .48 & .25 \\
\hline $\begin{array}{l}\text { KnowAgMarketing (a 1-5 knowledge scale in agricultural marketing. } 1=\text { Not at all, } \\
2=\text { Slightly, } 3=\text { Somehow, } 4 \text { = Very, } 5=\text { Extremely knowledgeable). }\end{array}$ & 1.21 & 2.21 & 3.35 & 2.3 \\
\hline $\begin{array}{l}\text { KnowAgEconomics (a 1-5 knowledge scale in agricultural economics. } 1=\text { Not at all, } \\
2=\text { Slightly, } 3=\text { Somehow, } 4=\text { Very, } 5=\text { Extremely knowledgeable). }\end{array}$ & 1.20 & 2.23 & 3.11 & 2.5 \\
\hline
\end{tabular}

These statistics indicate that respondents with a greater understanding of agricultural marketing and economic principles feel positively about their farm financial and profitability positions. The majority of small and mid-scale farmers who hold a college degree and those who use the best practices of farm management have positive feelings. This seems to suggest that an increase in education prepares farmers to face difficult financial times with optimism. This would concur with the findings by Panda (2015) that farmers with increased education see improved income. Likewise, most of full-time small and mid-scale farmers and those who utilize extension services feel the most positively. This seems to suggest that those who decide to depend primarily on income from their farm are in better positions to make the farms profitable to their fullest potential.

The majority of small and mid-scale farmers across almost all characteristics feel fairly about their farm financial and profitability positions. The statistics show that 48 percent of beginning farmers feel fairly about their farm financial and profitability position. The same percentage is true among beginning females. We found that 53 percent of full-time beginning small and mid-scale farmers feel fairly about their farm financial and profitability position as well. These findings are similar to Calo (2018) and Katchova (2010) who concluded that young and beginning farmers are much more likely to experience financial hardship.

\subsection{Regression Results}

Table 2 contains the coefficient estimates the feelings among small and mid-scale farmers in Kentucky about their farm financial and profitability positions. The coefficient estimates in the second column are the ordered log-odds; which measure the impact of corresponding independent variable on the chance of feeling positively over chances of feeling fairly or negatively. The $\mathrm{LR} \mathrm{Chi}^{2}$ of 53.67, and a p-value of 0.000 (one percent) indicate that the overall model is significant. This allows us to reject the null hypothesis that all regression coefficients in the model are equal to zero. We accepted the alternative hypothesis that at least one of the regression coefficients in the model is not equal to zero. The cut 1 and cut2 at the bottom of the table are estimated cut points on the latent variable used to differentiate negative and fair feelings from positive feelings when we valued independent variables at zero. 
Table 2. Coefficient Estimates from the Ordered Probit Regression

\begin{tabular}{lll}
\hline Ordered Probit Regression & Number of obs $=$ & 129 \\
& LR Chi $(16)=$ & 53.67 \\
Log likelihood $=-103.99129$ & Prob $>\mathrm{Chi}^{2}=$ & 0.0000 \\
\hline FeelingsFinancialPositionProfit & Pseudo $\mathrm{R}^{2}=$ & 0.2051 \\
\hline BeginningFarmers & Coefficients & Standard Errors \\
Beginning_Female & $-1.27^{* *}$ & $(.62)$ \\
FiftyandOlder & .51 & $(.49)$ \\
Fulltime_Beginners & $.54^{* *}$ & $(.23)$ \\
BPFM_User & -.38 & $(.49)$ \\
Female & .12 & $(.28)$ \\
FarmFullTime & $-1.65^{* * *}$ & $(.63)$ \\
Married & .32 & $(.31)$ \\
Married_Beginners & $-1.49^{* * *}$ & $(.56)$ \\
Educated_Female & .57 & $(.59)$ \\
Educated_Beginners & .06 & $(.45)$ \\
FourYearCollegeGrad & $-.71^{*}$ & $(.45)$ \\
Married_Female & $.53^{* *}$ & $(.34)$ \\
ExtensionGovFundUser & $-.93^{*}$ & $(.60)$ \\
KnowAgMarketing & $.16^{*}$ & $(.25)$ \\
KnowAgEconomics & $.29^{* * *}$ & $(.10)$ \\
\hline /cut1 & $.16^{* *}$ & $(.08)$ \\
/cut2 & -1.87 & $(.71)$ \\
\hline
\end{tabular}

Note. The $*, * *, * * *$ denote significance at $10 \%, 5 \%$, and $1 \%$ level, respectively.

The coefficient estimates in Table 2 show that the ordered odds for beginning small and mid-scale farmers to feel positively are 1.2721 times less than experienced farmers when all other predictors in the model are constant at their average values. This result relates to the fact that beginning farmers lack the necessary experience and knowledge to make their farms profitable at their fullest potential. They also may have more liabilities to pay back and less liquid assets to meet financial obligations. Another reason might be associated with operating farms too small to generate enough revenue. Similarly, D'Antoni et al. (2009) found that beginning farmers often lack the scale to be efficient.

We further found that being a female reduces the ordered odds to feel positively by 1.6584 times. This finding is similar to Galié (2013) who reported that women were more likely to face barriers to entering farm operations. Married small and mid-scale farmers are less likely to feel positively as well. In fact, the ordered odds are 1.9404 times lower among married compared to single ones. This may be due to the added stress many married couples face in their financial life such as having dependents who rely on them. We found that beginning farmers who were educated did not feel positive. One would expect the opposite. This highlights Ahearn's (2011) finding concerning problems for new farmers. Education may not help in certain issues such as the inability to obtain capital. Those who are educated do not feel significantly better, which may mean their problems do not stem from a lack of education but rather other financial issues. Educated beginning farmers might find that the opportunity cost (the value of their next best option) of owning a farm exceeds farm income.

On the other hand, results indicate that small and mid-scale farmers who are fifty and older are more likely to feel positive about their farm financial and profitability position than young farmers. Findings indicate that the ordered odds for older small and mid-scale farmers to have positive feelings are 0.5476 higher. While older farmers may be relatively likely to feel fairly or negatively, young farmers are even less likely to have positive outlooks (Ahearn, 2011; Katchova, 2010). As expected, results in Table 2 demonstrate that small and mid-scale farmers who grasp agricultural marketing and economic principles are more likely to feel positively. For one increased level of knowledge (on a 1-5 knowledge scale) about agricultural marketing, ordered odds to feel positively increase almost 30 percent. For one increased level of knowledge (on a 1-5 knowledge scale) about agricultural economics, the ordered odds for positive feelings increase almost 16 percent. This may also be tied 
to the fact that farmers with a college degree were also more likely to feel positive. Table 3 illustrates estimated probabilities for each of the three ordered levels of feeling and marginal effects associated with each of the explanatory variables. Results indicate that the likelihoods for small and mid-scale farmers to feel negatively, fairly, and negatively are 9 percent, 55 percent, and 36 percent respectively.

Table 3. Marginal effects

\begin{tabular}{llll}
\hline Independent Variables & Feel Negatively & Feel Fairly & Feel Positively \\
\cline { 2 - 4 } & Probability $=09 \%$ & Probability $=55 \%$ & Probability $=36 \%$ \\
\hline BeginningFarmers & $.23^{*}$ & $.19^{* * *}$ & $-.43^{* * *}$ \\
Beginning_Female & -.06 & -.12 & .19 \\
FiftyandOlder & $-.08^{* *}$ & $.11^{* *}$ & $.20^{* * *}$ \\
Fulltime_Beginners & .07 & .05 & -.13 \\
BPFM_User & -.02 & -.02 & .04 \\
Female & $.35^{* *}$ & $.16^{* * *}$ & $-.52^{* * *}$ \\
FarmFullTime & -.04 & -.07 & .12 \\
Married & $.15^{* * *}$ & $.38^{* * *}$ & $-.54^{* * *}$ \\
Married_Beginners & -.08 & -.13 & .22 \\
Educated_Female & -.01 & -.01 & .02 \\
Educated_Beginners & .14 & $.09 * * *$ & $-.24^{* *}$ \\
FourYearCollegeGrad & -.08 & -.11 & $.19^{* *}$ \\
Married_Female & $.12^{* *}$ & -.23 & .35 \\
ExtensionGovFundUser & .01 & .01 & $.12^{*}$ \\
KnowAgMarketing & $-.04 * * *$ & $-.06^{* * *}$ & $.10^{* * *}$ \\
KnowAgEconomics & $-.02^{* *}$ & $-.03^{*}$ & $.06^{* *}$ \\
\hline
\end{tabular}

Note. The *, **, ${ }^{* * *}$ denote significance at $10 \%, 5 \%$, and $1 \%$ level, respectively.

As indicated in Table 3 above, the overall probability for small and mid-sized farm owners to feel negatively about their farm financial and profitability positions is 9 percent. This probability increases by almost 24 percent for beginning farmers. Older small and mid-scale farmers are barely 9 percent less likely to have negative feelings than relatively younger ones. Compared to their counterparts, females are 35 percent more likely to feel negative about farm financial and profitability positions. This finding echoes Sarworsi et al. (2016); Beaman et al. (2013) who acknowledged that women farmers face unique conditions. We further found that married small and mid-scale farms were 16 percent more likely to feel negatively. Married females are 12 percent more likely to feel negatively. Results show that for one level of knowledge about agricultural marketing, there is almost 5 percent lower chance of feeling negatively about farm financial and profitability position. That probability is 3 percent lower for an additional level of knowledge about agricultural economics.

The overall probability for small and mid-sized farm owners to fell positively about their farm financial and profitability positions is 36 percent. We found that beginning farmers are 44 percent less likely to feel positively about their farm operations; when compared with experienced farmers. Results in Table 3 indicate further that older small and mid-scale farmers are barely 20 percent more likely to have positive feelings towards the financial and profitability position of their farms. This finding suggests that most of these farmers have extensive farming experience on mid-scale farm operations. It is also possible that several of these farmers own their farms/ranches, and therefore do not have a lot of farm-related liability to pay back. We found that female and married small and mid-scale farmers are 52 percent and 54 percent less likely to have positive feelings, respectively. This study also realized that educated beginning small and mid-scale farmers are less likely to feel positively about their farm financial and profitability position. They are 24 percent less likely. As previously argued about beginning farmers, this category of farmers is still in the early stage of farming/ranching and therefore have not yet settle their farm finances and/or improve farm profitability.

Results show that education makes a difference. We found that having a 4-year college degree increases the likelihood of feeling positively by approximately 20 percent. Given the fact that educated beginning farmers are less likely to feel positively, it is clear that education and experience play a great role. This study's findings showed that small and mid-scale farmers who use extension services and/or any other form of government 
funding are 12 percent more likely to have positive feelings. This result suggests that the work of extension agencies is important in shaping farmer's attitudes towards his/her financial and profitability position. In fact, Jablonski et al. (2017) concluded that these programs are effective in assisting farmers.

Findings from this study further indicated that one additional level of knowledge about agricultural marketing increases the likelihood of feeling positively about farm financial and profitability position by 11 percent. An extra level of knowledge about agricultural economics increases the probability of positive feelings about farm financial and profitability position by 6 percent. These last two findings suggest that it is useful for current and future farmers to develop a great knowledge about agricultural marketing and agricultural economics. Similar to Panda (2015), there is a significant evidence that understanding economic principles and agri-marketing makes farmers feel better.

As previously noted, the majority of small and mid-scale farmers in Kentucky across several farmer characteristics feel fairly about financial and profitability position. Results indicate that the overall probability for this feeling is 55 percent. This means that several of these farmers consider their farm financial and profitability to be acceptable/satisfactory. They do not clearly feel neither negative nor positive. While we found that beginning small and mid-scale farmers less likely to feel positively, there is a 20 percent chance, they feel fairly about their farm financial and profitability position. Older farmers are almost 12 percent more likely to consider their farm position as acceptable, while females are 17 percent more likely to do so. Compared to singles, married small and mid-scale farmers are approximately 39 percent more probable to have satisfactory feelings. Results indicate further that educated beginning farmers are 9 percent more likely to feel fairly. This study showed that for one level of knowledge about agricultural marketing, there is almost 6 percent lower likelihood of considering farm financial and profitability position satisfactory. For one level of knowledge about agricultural economics, the likelihood of considering farm financial and profitability position acceptable decreases by 3 percent.

\section{Concluding Remarks}

The feelings among small and mid-scale farmers about their farm financial and profitability remained unclear. This study used mailed and online survey data collected in 2017 from 129 small and mid-scale farmers in Kentucky. It has focused on (a) estimating ordered odds and relative probabilities for small and mid-scale farmers to feel positively, fairly, or negatively respectively, (b) explaining significant factors that influence feelings that small and mid-scale farmers have about their farm financial position and profitability position, and (d) determining the probability difference between beginning farmers and experienced farmers regarding the feelings. The study employed an ordered Probit model. Findings indicated that the likelihoods for small and mid-scale farmers to feel negatively, fairly, and positively are 9 percent, 55 percent, and 36 percent, respectively. Beginning farmers were significantly more likely to feel negatively about their farm financial and profitability position than experienced ones. Results indicated that marriage, female, and beginning farmers increase the probability of feeling fairly. We found that knowledge about agricultural marketing and agricultural economics increases the likelihood of feeling positively, as would be expected due to increased business acumen. This study identified clearly farmer characteristics with significant effects on each of the three levels of feeling.

Results from this study revealed a few possible suggestions. For example, the finding that farmers who utilize extensions and other farm-related government programs feel positively calls for increased funding to continue shaping positive feelings among beneficiaries. It is true that association is not causation, but our results indicated that farmers who are able to utilize extension services consistently felt better about their finances than those that did not. The fact that farmers who understand agriculture marketing and economics feel better about their financial and profitability position encourages educators and trainers. It also advocates for future funding to include more resources to enhance producer knowledge on these topics. This study leaves room for future research. Further research studies should focus on those who have negative feelings and identify strategies to reverse them.

\section{References}

Ahearn, M. (2011). Potential Challenges for Beginning Farmers and Ranchers. Choices: The Magazine of Food, Farm, and Resource Issues, Agricultural and Applied Economics Association, 26(2), 1-6.

Austin, K., \& Mohammed, A. (2013). An Econometric Analysis of Factors from the Farmers' perspective that Affect Profitability of Tilapia Production in Trinidad. Caribbean Food Crops Society, 49, 9-21. 
Beaman, L. A., Karlan, D., Thuysbaert, B., \& Udry, C. R. (2013). Profitability of Fertilizer: Experimental Evidence from Female Rice Farmers in Mali. American Economic Review, 103(3), 381-386. https://doi.org/ 10.1257/aer.103.3.381

Calo, A. (2018). How Knowledge Deficit Interventions Fail to Resolve Beginning Farmer Challenges. Agriculture and Human Values, 35(2), 367-81. https://doi.org/10.1007/s10460-017-9832-6

D'antoni, J., Mishra, A. K., \& Chintawar, S. (2009). Predicting Financial Stress in Young and Beginning Farmers in the United States. Selected Paper Prepared for Presentation at the Southern Agricultural Economics Association Annual Meeting, January 31-February 3, 2009, Atlanta, Georgia. Retrieved from https://ageconsearch.umn.edu/record/46861?ln=en

Dedehouanou, S., \& Maertens, M. (2011). Participation in Modern Agri-Food Supply Chain in Senegal and Happiness. 2011 International Congress, August 30-September 2, 2011, European Association of Agricultural Economists, Zurich, Switzerland. Retrieved from https://ageconsearch.umn.edu/record/ $114447 ? \ln =$ en

Frey, B. S. (2018). Economics of Happiness. Cham: Springer International Publishing. https://doi.org/10.1007/ 978-3-319-75807-7

Galié, A. (2013). Empowering Women Farmers: The Case of Participatory Plant Breeding in Ten Syrian Households. Frontiers: A Journal of Women Studies, 34(1), 52-92. https://doi.org/10.5250/fronjwomestud. 34.1.0058

Jablonski, B., McFadden, D., Sullins, M., \& Curtis, K. (2017). Determinants of Effective Beginner Farming Progamming and Implications of Future Programs. Journal of Agricultural and Resource Economics, 42(3), 427-438.

Katchova, A. L. (2010). An Analysis of the Financial Performance of Beginning Farmers. Selected Paper Prepared for Presentation at the Agriculture and Applied Economics Association annual meeting, July 25-27, 2010, Denver, Colorado. Retrieved from https://ageconsearch.umn.edu/record/61513/?ln=en

Kennedy, P. (2008). A Guide to Econometrics (6th ed.). Malden, Massachusetts: Blackwell Publishing.

Latvala, T., \& Pyykkonen, P. (2005). Profitability of and Reasons for Adopting Automatic Milking Systems. European Association of Agricultural Economists Annual Meeting, 1-3. https://oi.org/10.22004/ag. econ. 24534

Maharajh, S., Pemberton, C., Sormeaux, A. D., \& Patterson-Andrews, H. (2018). Are Cocoa Farmers in Trinidad Happy? Exploring Factors Affecting Their Happiness. The Journal of the Caribbean Agro-Economic Society, 10(2), 14-32.

Mishra, A. K., El-Osta, H. S., Morehart, M. J., Johnson, J. D., \& Hopkins, J. H. (2002). Income, Wealth, and the Economic Well-Being of Farm Households. Agricultural Economic Report No. 812.

Möllers, J., Zier, P., Frohberg, K., Buchenreider, K., \& Bojnec, S. (2009). Studies on the Agricultural and Food Sector in Central and Eastern Europe. Retrieved from https://www.iamo.de/fileadmin/documents/ sr_vol48.pdf

Nambiro, E., Omiti, J., \& Mugunieri, L. (2006). Decentralization and Access to Agricultural Extension Services in Kenya. Association of Agricultural Economist, Gold Coast, Australia, 1-13. Retrieved from https://ageconsearch.umn.edu/record/25246

O'Leary, N., Tranter, R., \& Bennett, R. (2017). Farmer Attitudes Predictive of Profitability. Retrieved from https://ageconsearch.umn.edu/record/258638? $\mathrm{ln}=\mathrm{en}$

Panda, S. (2015). Farmer Education and Household Agricultural Income in Rural India. International Journal of Social Economics, 42(6), 514-29. https://doi.org/10.1108/ijse-12-2013-0278

Poczta-Wajda, A. (2015). Feeling of Relative Deprivation as a Driver for Higher Agricultural Subsidies. Problems of World Agriculture, 15(30), 1-10.

Samdup, T., Udo, H. M., \& Van der Zijpp, A. J. (2014). A Participatory Framework to Identify Gross National Happiness Issues for the Development of Smallholder Mixed Farming Systems in Bhutan. Asian Journal of Agriculture and Development, 11(1), 1-19. 
Sarwosri, A., Römer, U., \& Musshoff, O. (2016). Are African Female Farmers Disadvantaged on the Microfinance Lending Market? Agricultural Finance Review, 76(4), 477-93. https://oi.org/10.1108/ afr-02-2016-0012

Train, K. E. (2009). Discrete Choice Methods with Simulation (2nd ed.) New York City: Cambride University Press. https://doi.org/10.1017/CBO9780511805271

U.S. Department of Agriculture. (2019). Beginning Farmers and Ranchers Loans. Retrieved from https://www. fsa.usda.gov/programs-and-services/farm-loan-programs/beginning-farmers-and-ranchers-loans/index

\section{Copyrights}

Copyright for this article is retained by the author(s), with first publication rights granted to the journal.

This is an open-access article distributed under the terms and conditions of the Creative Commons Attribution license (http://creativecommons.org/licenses/by/4.0/). 